\title{
Caking of Urea in Summer Season
}

\section{(A Case study)}

\author{
Prem Baboo \\ Sr. Manager (Prod) \\ National Fertilizers Ltd. India \\ Sr. Advisor of www.ureaknow.com
}

\begin{abstract}
In India the ambient temperature goes to $46-48^{\circ} \mathrm{C}$ in peak summer. The prills temperature goes to higher i.e.in our plants, line-1- prills temperature is $7^{70-72} \mathrm{C}$ and sometime reached $7^{\circ} \mathrm{C}$ at higher plant load with recovery of urea solution and that of line-2- prills temperature is $64-66^{\circ} \mathrm{C}$ without Bulk Flow cooling. The caking of urea fertilizer is investigated in a ware house of large scale in National Fertilizers plant. In this article the caking tendency of urea investigated in silo and urea bags. The main cause of caking is the growth of crystal bond on contact point of prills, the caking tendency increases with moisture, ammonia contents causes water to mitigate through the pile. This to increases the caking tendency. The effect of plant load, temperature, relative humidity, and storage time on the formation of a bridge between these particles was analysed. The objective was to describe the geometrical changes in the contact region and to measure the strength of the resulting inter particle bridge. Urea particles are used which are known for creating solid bridges under well-defined climatic conditions. The measurements indicate that unlike to isotropic materials the bridge between two particles has higher shear than tensile strength. Moreover, the strengthening of the bridges with storage time is very inhomogeneous. The effect of load, temperature, relative humidity, and storage are the main objective of the study.
\end{abstract}

Key word - Lumps, humidity, Prills, caking, bulk flow cooler, vacuum, temperature, Prills size distribution. Urea dust, silo. CRH.

\section{INTRODUCTION}

National Fertilizers Ltd, (NFL) operates a fertilizer complex at Vijaipur, Distt. Guna (Madhya Pradesh), India consisting of two units Vijaipur-I and Vijaipur-II, plants were commissioned in December 1987 and March 1997 respectively. Ammonia Plants are based on M/s. HTAS's Steam Reforming of Natural Gas and Urea plants are based on M/S. Saipem's Ammonia Stripping Technology. NFL, a Schedule 'A' \& a Mini Ratna (Category-I) Company. The Vijaipur unit, which is an ISO 9001:2000 \& 14001 certified, comprises of two streams. The Vijaipur have two ammonia plant M/S. Haldor Topsoe Technology, Denmark capacity $1750 \& 1864$ TPD for Line-I \& line-II respectively and four urea plant of M/S. Saipem ammonia stripping process, Italy. The capacity of Urea-I urea -II is 3030 \& 3231 TPD respectively. Urea line-1 \&2 have Solex bulk flow cooler which have laminar flow without bridging and blocking and Discharge similar as in vertical silos. All particles move at the same velocity and No dead zones. Combines the principles of conductive heat transfer and mass flow rate controlled by a level probe.

\section{Mechanism of Urea Caking}

Most fertilizers have some tendency to form lumps or caking during storage. Urea prills readily absorb moisture from the atmosphere, which leads to caking, a decrease in dynamic strength and increased dust formation.

The mechanism of caking in fertilizers is most often attributed to the formation of salt bridges and/or capillary adhesion. The severity of caking can be influenced by a number of factors, such as-

1. Chemical composition.

2. Moisture content

3. Free ammonia particle structure

4. Mechanical strength,

5. Crushing strength

6. Product temperature

7. Ambient conditions, storage time

8. Hygroscopic properties

9. Storage pressure

The various methods of reducing or eliminating caking in fertilizers basically involve process control, to reduce temperature of urea, storage/packaging conditions, and/or addition of anticaking agents. Caking of fertilizer is caused by the formation of contact points between the particles of prills. These contact points differ in nature and can be divided into three types, namely,

1. Phase contacts,

2. Adhesive contacts, and

3. Liquid contacts.

Phase contacts are crystal bridges formed at the contact points between the urea particles. The most troublesome caking of fertilizers is believed to be caused by urea crystal bridging. Urea Crystal bridges develop during storage as a result of continuing internal chemical reactions, dust in the product dissolution/recrystallization processes, and/or thermal effects.

\section{External Factors}

Size distribution of the prills. Both lower size \& oversize are dangerous. The proper size shown in the table No.5.Adhesive contacts are formed as a result of molecular attraction between the surfaces in contact. These forces of attraction are considered to be relatively weak. This type of contact is influenced mostly by the plasticity of the particles of urea and the pressure exerted on the urea material when it is stacked in bags or piled in bulk in railway waggon or 
truck loading. The condition is usually referred to as bag or pile set, and the material normally reverts to a free-flowing form rather easily with a minimal amount of handling. Storage period of 3 to 5 months is suggested for urea fertilizers. Storage conditions (temperature, humidity etc.) are specified. Storage under high humidity (more than 80\%) is reported to cause higher moisture content of urea fertilizers than recommended. Liquid contacts are due to considerable wetting of the urea, which causes films of a saturated solution to form between urea particles. Formation of these types of contact points is defined as 'sticking'. Although such 'sticking' has little strength, it is obviously undesirable. The handling and storage of urea requires special attention to several product related properties and external factors. Most common problems are associated with moisture pick up, caking, dustiness and particle segregation. The factors that most affect the moisture absorptionpenetration characteristics of urea are its chemical composition, particle porosity, particle surface area, and degree of crystallinity.

\section{Internal factors}

Internal factors the moisture /ammonia contents of the product are usually considered to be the most important factor in promoting caking. For most caking mechanisms as following. -

1. The presence of moisture

2. High Temperature of urea

3. Free Ammonia in prills

Generally, the higher the degree of drying at the time of manufacture, the less active the caking mechanisms will be the extent of drying required to effectively inactivate caking mechanisms varies rather widely with the composition and physical makeup of the fertilizer

The chemical composition has an effect on the caking tendency of a Urea. E.g., it has been observed that the caking tendency of ammonium nitrate $\mathrm{NH}_{4} \mathrm{NO}_{3}$-based and urea-based NPK fertilizers is significantly greater than that of ammonium sulphate (NH4) 2 SO4-based and ammonium phosphate-based NPK fertilizers. Even impurities may affect caking. The size and shape of the urea particles are also important. If the particles are relatively large or smaller i.e. undersize, well formed, and uniform in size and shape with very little fine material, the specific surface area is reduced. Consequently, forces of attraction and points of contact between adjacent particles are reduced, lowering the tendency to cake. The mechanical strength or hardness of the particles has an effect on the caking tendency. Weak urea particles may break down under stack or pile pressure (crushing strength) or during handling (abrasion and impact strength). The large size urea prills having less crushing strength due to hollow prills. The free ammonia also affects the prills strength. As a result, a substantial quantity of fines can be created, thereby increasing the number of contact points between particles. The hygroscopic properties of the urea can have an effect on the degree of caking. All fertilizers have a maximum relative humidity (referred to as the critical relative humidity $(\mathrm{CRH})$ above which they will absorb moisture, as shown in the table-2. Prilling tower have variable opening louvers system, this helps to control air intake flow to prilling tower at bottom, which is very useful in rainy seasons as CRH (critical relative humidity) of urea becomes less than atmospheric humidity and prills tends to absorb moisture from air. $\mathrm{CRH}=\mathrm{Ps} / \mathrm{Pa}$, where, $\mathrm{Ps}=$ Vapour pressure of saturated urea solution at given temperature. $\mathrm{Pa}=$ Vapor pressure of pure water at same temperature. Critical relative humidity, at $20^{\circ} \mathrm{C}: 81 \%$ at $30^{\circ} \mathrm{C}$ : $73 \%$ The $\mathrm{CRH}$, a unique material property, is generally lowered when the material contains impurities or is mixed with other fertilizer salts. Critical Relative Humidity $(\mathrm{CRH})$ is the value of the relative humidity of the surrounding air, above which a fertilizer will absorb moisture and below which it does not absorb moisture. As shown in the table No.3. CRH value of fertilizer is required while designing controlled humidity of storage areas for a fertilizer. Critical relative humidity of urea is high (70 to 75 at $30^{\circ} \mathrm{C}$ ) compared to the Ammonium Nitrate and Calcium Ammonium Nitrate (CAN). So, it can withstand the hot and humid conditions in India .Caking as a result of moisture absorption usually occurs along the pile surface with prolonged exposure of the urea to elevated humidifies, caking can become quite deep. The hygroscopic nature of a urea product, along with urea temperature, ambient temperature, and atmospheric relative humidity, and free ammonia in prills also influences the mass transfer of moisture through a bulk pile of urea. Transfer of moisture through a pile of urea can cause severe caking problems. The temperature of the urea when placed in storage influences caking tendency. Higher temperatures increase the chemical reactivity, such as the re-evaporation of water, which results in re-crystallization and formation of solid crystalline bridges. To investigate the formation and growth of solid bridges between two discrete particles, the modification of the contact region between these two particles stored in a climatic chamber is examined. Additionally, a high urea temperature can promote particle plasticity causing the particles to deform under pressure. This deformation promotes both crystal bridging and capillary adhesion. Urea being fed to the stockpile at $65^{\circ} \mathrm{C}$ to $70^{\circ} \mathrm{C}$ will definitely form strong cakes. The lower the feed temperature, the lower the tendency to cake. The conclusion of the study was that if the prills are cooled below $50^{\circ} \mathrm{C}$ before entering storage, there is less agglomeration and, mainly, the agglomerates are softer which can be easily break down.

\section{How to reduce Caking Problem?}

Following actions have been taken to reduced caking

1. To Control moisture in Prills

2. To reduce Prills temperature with Bulk Flow Cooler

3. To reduce Ammonia contents in prills with process conditions

4. Urea dust removing from urea prills in conveying system and BFC.

1. Moisture Control

The internal moisture in urea prills control by process condition, i.e. to control vacuum in the proper and near to 
designed value as per temperature. The table No. -1 shows the prills moisture Vs. Vacuum. Also vacuum improved by plant upstream conditions i.e. Conversion in reactor heat exchangers, Stripper, MP decomposer \& L.P decomposers temperature and pressures.

\begin{tabular}{|c|c|c|c|c|c|c|c|}
\hline \multicolumn{9}{|c|}{ Vacuum Urea melt and Free Ammonia in Prills } \\
\hline & Plant Load & $107.0 \%$ & Plant & Urea-II & Date & \multicolumn{2}{c|}{$28-05-2018$} \\
\hline $\begin{array}{c}\text { Sr. } \\
\text { No. }\end{array}$ & $\begin{array}{c}\text { Pre-Concentrator } \\
\text { Vacuum }\end{array}$ & $\begin{array}{c}\text { Vacuum } 1^{\text {st }} \text { stage } \\
\text { Evaporator }\end{array}$ & $\begin{array}{c}\text { Vacuum } 2^{\text {nd }} \text { stage } \\
\text { Evaporator }\end{array}$ & $\begin{array}{c}\text { Urea Melt } \\
\text { Temp }\end{array}$ & Biuret & Moisture & $\begin{array}{c}\text { Free Ammonia } \\
\text { in Prills }\end{array}$ \\
\hline & ata & ata & ata & ${ }^{\circ}$ C & $\%$ & $\%$ & ppm \\
\hline 1 & 0.555 & 0.567 & 0.078 & 140.0 & 1.100 & 0.400 & 151.3 \\
\hline 2 & 0.500 & 0.550 & 0.070 & 139.5 & 1.070 & 0.390 & 148.0 \\
\hline 3 & 0.450 & 0.500 & 0.065 & 139.0 & 1.020 & 0.380 & 145.0 \\
\hline 4 & 0.440 & 0.480 & 0.060 & 138.5 & 1.000 & 0.360 & 139.50 \\
\hline 5 & 0.430 & 0.470 & 0.050 & 138.0 & 0.980 & 0.340 & 135.30 \\
\hline 6 & 0.420 & 0.450 & 0.040 & 138.0 & 0.970 & 0.300 & 129.40 \\
\hline 7 & 0.410 & 0.440 & 0.030 & 137.0 & 0.965 & 0.280 & 122.30 \\
\hline 8 & 0.400 & 0.430 & 0.030 & 136.8 & 0.920 & 0.260 & 112.00 \\
\hline 9 & 0.340 & 0.410 & 0.030 & 136.0 & 0.812 & 0.250 & 102.50 \\
\hline 10 & 0.330 & 0.400 & 0.029 & 135.0 & 0.734 & 0.240 & 92.00 \\
\hline 11 & 0.320 & 0.380 & 0.028 & 134.5 & 0.730 & 0.230 & 74.00 \\
\hline 12 & 0.320 & 0.330 & 0.028 & 134.3 & 0.630 & 0.220 & 58.00 \\
\hline
\end{tabular}

Observed from above table the free ammonia is the function of vacuum, poor vacuum can cause higher ammonia, less vacuum causes high moisture, high free ammonia and less crushing strength of urea prills. Also when biuret is increases one mole of ammonia also released as following equation. Formation of biuret takes place when urea is heated to its melting point it starts decomposition with evolution of ammonia, urea first isomerizes which dissociates into isocynic acid and ammonia.

$\mathrm{CO}\left(\mathrm{NH}_{2}\right)_{2} \quad=\mathrm{NH}_{4} \mathrm{CNO}+\mathrm{NH}_{3}$

(UREA) (AMM.CYNATE)

The isocynic acid reacts with urea to form biuret.

$\mathrm{NHCO}+\mathrm{CO}\left(\mathrm{NH}_{2}\right)_{2}=\mathrm{NH}_{2} \mathrm{CONHCONH}_{2}$

Biuret

In the presence of excess ammonia biuret is formed at substantially lower rate by direct reaction between urea molecules.

$2 \mathrm{CO}\left(\mathrm{NH}_{2}\right)_{2}=\mathrm{NH}_{2} \mathrm{CONHCONH}_{2}+\mathrm{NH}_{3}$.

(UREA) BIURET AMMONIA

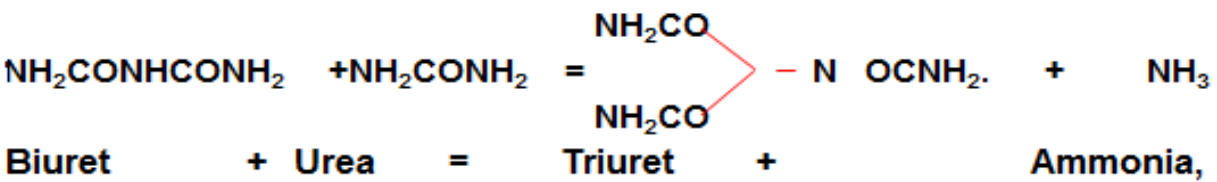

Biuret Favorable Condition-

1. High temperature, low pressure

2. High residence time.

3. High concentration

4. Low Ammonia.

2. To reduce Prills Temperature with Solex Bulk Flow Cooler

The Solex Bulk Flow cooler have been installed in line-1 \&2 plant since 2012.In peak summer when prills temperature reached more than $60^{\circ} \mathrm{C}$ then $\mathrm{BFC}$ have to be taken in line to cool down prills temperature. In BFC all particles move at the same velocity, No dead zones Laminar flow without bridging and blocking, Discharge similar as in vertical silos. Combines the principles of conductive heat transfer and mass flow. The flow rate controlled by a level probe which is installed upper part of the BFC. Main components of the Solex Heat Exchanger

1. Vertical Plates offer the necessary heat exchange area

2. Gate feeder: guarantees mass flow of the product

3. Level Control maintains the product level above the plates during operation.

The design point of view it is fully welded with Stainless Steel (316L \& 304L), turbulent water flow for even temperature distribution and flexible stainless steel hoses to connect the plates with the manifolds. All connections outside the product flow. The cooler have modular construction,Plate banks can be added on top of each other to obtain required cooling \&performanc. The Solex bulk flow cooler is designed for $155 \mathrm{MT} / \mathrm{hr}$ Urea,Cooling Urea from $75{ }^{\circ} \mathrm{C}$ until $60{ }^{\circ} \mathrm{C}$, and closed cooling water loop (69 $\mathrm{m}^{3} / \mathrm{h}$ ) with inlet temperature of $36{ }^{\circ} \mathrm{C}$ and outlet temperature of $54{ }^{\circ} \mathrm{C}$.Purge air $1500 \mathrm{~m}^{3} / \mathrm{h}$ with dew point below $18{ }^{\circ} \mathrm{C}$. 
The flow diagram shown an figure No. 1

The BFC Heat Exchanger has many advantages:

1. Lower investment costs

2. Lower operation costs

3. No product degradation

4. High cooling efficiency

5. Low energy consumption
6. Low purge air, very low air emission

7. No moving parts, no maintenance

The BFC heat exchanger is an economical solution for the cooling of fertilizers even in India with high ambient temperatures and high moist content of the ambient air.Hot fertilizers can be cooled in BFC plate heat exchangers without fouling of the cooler, when a sufficient amount of purge air is used in the appropriate parts of the cooler

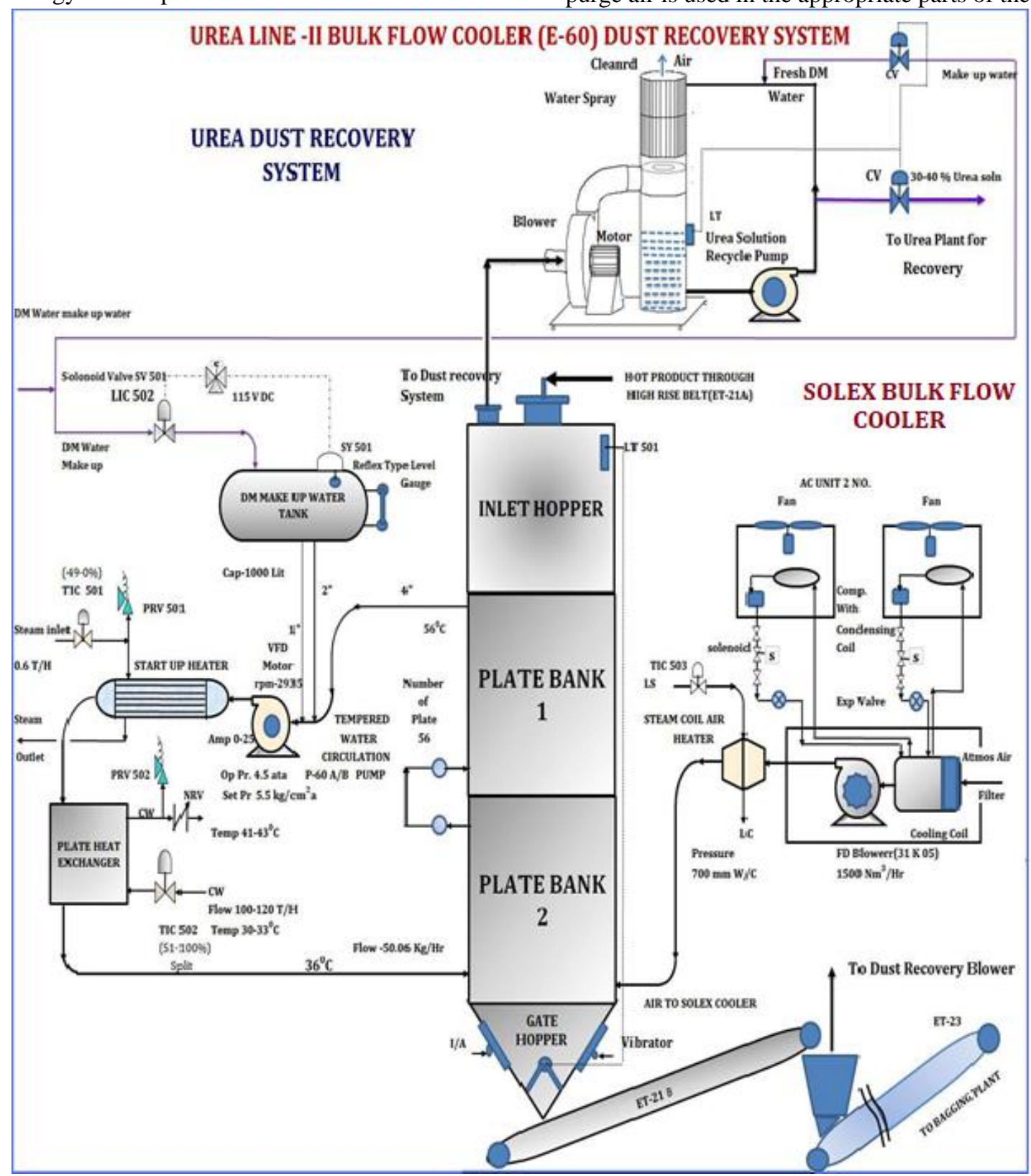

Fig-1: Flow diagram of Solex cooler 


\begin{tabular}{|c|c|c|c|c|c|c|c|c|}
\hline 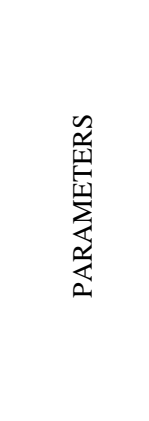 & $\sum_{\underline{\mid l}}^{\underline{\mid c}}$ & 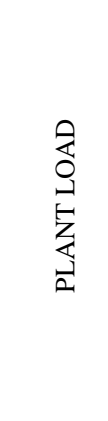 & 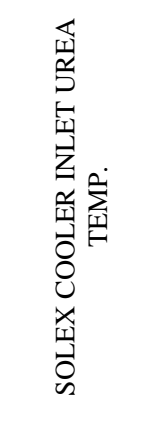 & 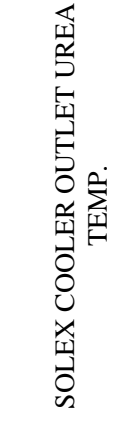 & 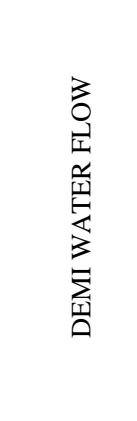 & 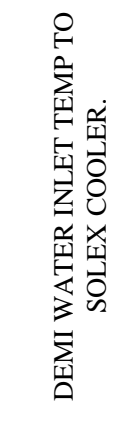 & 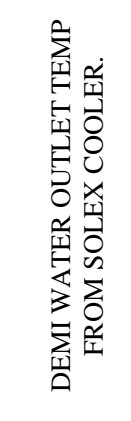 & 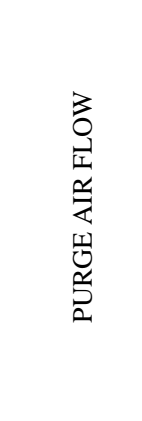 \\
\hline TAG NO. & & --- & 11TTR503 & 11TTR504 & 11FTR501 & 11TIC501 & 11TIC501 & 11FRC504 \\
\hline Date & Hrs & $\mathrm{MT} / \mathrm{H}$ & ${ }^{0} \mathrm{C}$ & ${ }^{0} \mathrm{C}$ & $\mathrm{m} 3 / \mathrm{h}$ & ${ }^{0} \mathrm{C}$ & ${ }^{0} \mathrm{C}$ & $\mathrm{Nm} 3 / \mathrm{h}$ \\
\hline \multirow{4}{*}{ 07-05-2018 } & Design & 155 & 75.0 & 60.0 & 50.0 & 36.0 & 56.0 & 1500 \\
\hline & $11.00 \mathrm{Hrs}$ & 125 & 78.0 & 57.3 & 53.0 & 37 & 57.1 & 1511 \\
\hline & $14.00 \mathrm{Hrs}$ & 125 & 79.0 & 58.1 & 51.0 & 37.2 & 57.5 & 1523 \\
\hline & $18.00 \mathrm{Hrs}$ & 125 & 77.0 & 56.2 & 52.5 & 37.3 & 57.8 & 1524 \\
\hline \multirow{3}{*}{ 08-05-2018 } & $11.00 \mathrm{Hrs}$ & 125 & 78.0 & 57.3 & 53.0 & 37 & 57.1 & 1511 \\
\hline & $14.00 \mathrm{Hrs}$ & 125 & 79.0 & 58.1 & 51.0 & 37.2 & 57.5 & 1523 \\
\hline & $18.00 \mathrm{Hrs}$ & 125 & 77.0 & 56.2 & 52.5 & 37.3 & 57.8 & 1524 \\
\hline \multirow{3}{*}{ 09-05-2018 } & $11.00 \mathrm{Hrs}$ & 125 & 78.0 & 57.3 & 53.0 & 37 & 57.1 & 1511 \\
\hline & $14.00 \mathrm{Hrs}$ & 125 & 79.0 & 58.1 & 51.0 & 37.2 & 57.5 & 1523 \\
\hline & $18.00 \mathrm{Hrs}$ & 125 & 77.0 & 56.2 & 52.5 & 37.3 & 57.8 & 1524 \\
\hline
\end{tabular}

Table-2 : Operating conditions in NFL line 1

The second option is to add dry purge air to reduce the dewpoint of the air between the prills. Recommended was the use of $1500 \mathrm{Nm} 3 / \mathrm{h}$ purge air with dew point below $18{ }^{\circ} \mathrm{C}$ which should reduce the dew point enough to prevent condensation at the designed cooling water inlet temperature of $38{ }^{\circ} \mathrm{C}$ and outlet temperature of $54{ }^{\circ} \mathrm{C}$. When applying purge air to the bottom gate hopper it was observed that the minimum opening had to be reduced to keep the level in the inlet hopper. Hot urea can be cooled in Solex plate heat exchangers without fouling of the cooler, when a sufficient amount of purge air is used in the appropriate parts of the cooler. The performance of the Solex BFC is very simple and we haven't had any issues with cooling or bridging. Solex heat exchangers cool bulk solids using indirect heat transfer by conduction to substantially reduce energy requirements. The Soles urea cooling technology uses indirect heat transfer, keeping air and fluid completely separate from the product being cooled. The Solex heat exchanger designs can use a variety of different heat transfer fluids including water, steam other fluids. 


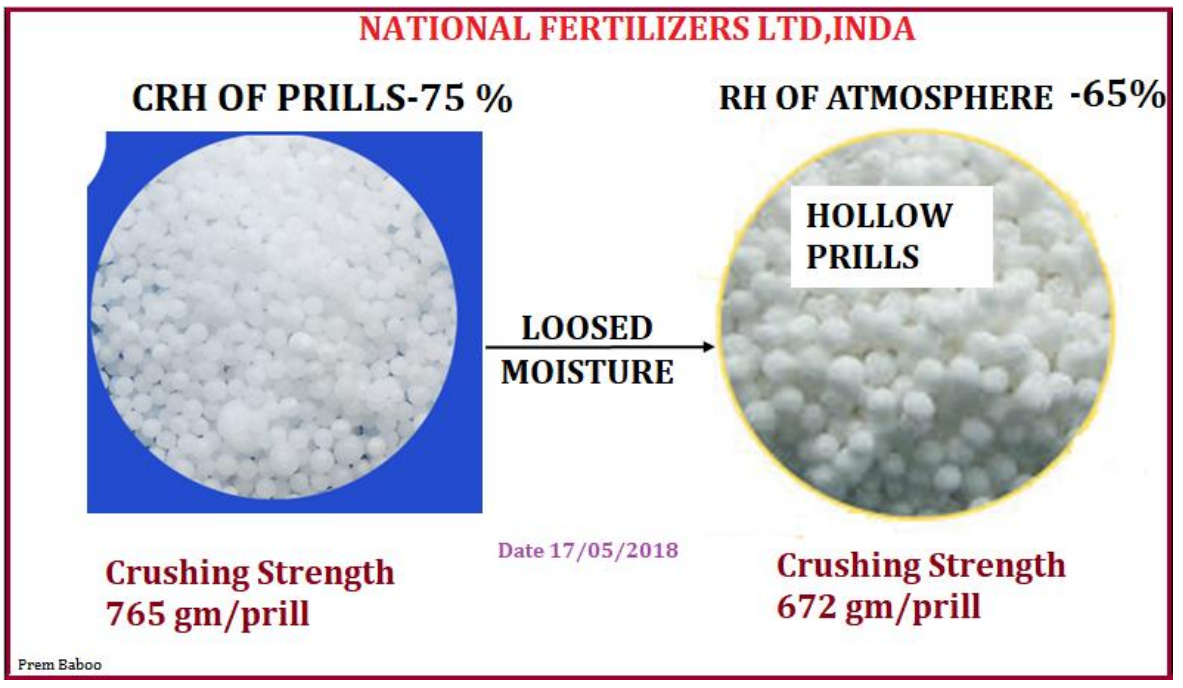

Fig -2: The influence of moisture on crushing strength

The Urea CRH value ranges from $70-75 \%$ at $30^{\circ} \mathrm{C}$. the table below provides the $\mathrm{CRH}$ value of Urea at different temperatures.

\begin{tabular}{|c|c|c|c|c|c|c|c|}
\hline Temperature & 10 & 15 & 20 & 25 & 30 & 40 & 50 \\
\hline CRH \% & 81.8 & 79.9 & 80 & 75.8 & 72.5 & 68 & 62.5 \\
\hline
\end{tabular}

\begin{tabular}{|c|c|c|c|c|c|c|c|c|}
\hline 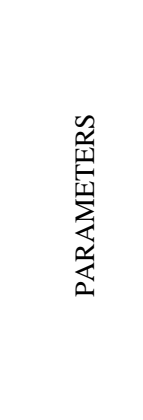 & $\sum_{i=1}^{\omega}$ & 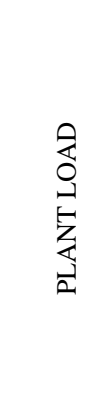 & 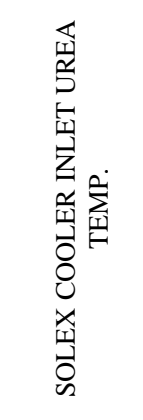 & 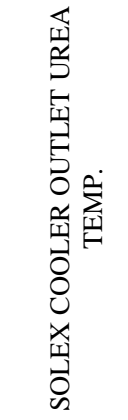 & 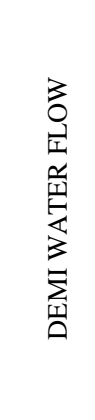 & 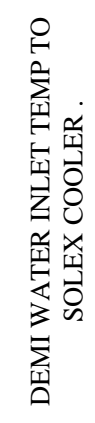 & 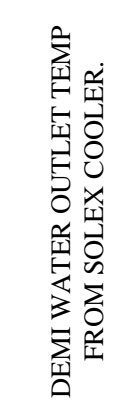 & 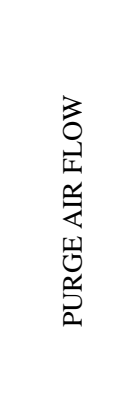 \\
\hline TAG NO. & & --- & 11TTR503 & $\begin{array}{c}\text { 11TTR50 } \\
4 \\
\end{array}$ & $\begin{array}{c}\text { 11FTR } \\
501\end{array}$ & $\begin{array}{c}11 \mathrm{TIC} \\
501 \\
\end{array}$ & 11TIC501 & $\begin{array}{c}\text { 11FRC50 } \\
4 \\
\end{array}$ \\
\hline Date & Hrs & $\mathrm{MT} / \mathrm{H}$ & ${ }^{0} \mathrm{C}$ & ${ }^{0} \mathrm{C}$ & $\mathrm{m} 3 / \mathrm{h}$ & ${ }^{0} \mathrm{C}$ & ${ }^{0} \mathrm{C}$ & $\mathrm{Nm} 3 / \mathrm{h}$ \\
\hline \multirow{4}{*}{ 01-05-2018 } & Design & 155 & 75.0 & 60.0 & 50.0 & 36.0 & 56.0 & 1500 \\
\hline & $11.00 \mathrm{Hrs}$ & 146 & 69.1 & 56.3 & 51.0 & 35.8 & 55.5 & 1485 \\
\hline & $14.00 \mathrm{Hrs}$ & 146 & 70.4 & 57.8 & 50.1 & 35.7 & 56.5 & 1470 \\
\hline & $18.00 \mathrm{Hrs}$ & 146 & 68.6 & 55.6 & 49.6 & 35.8 & 54.6 & 1450 \\
\hline \multirow{3}{*}{ 02-05-2018 } & $11.00 \mathrm{Hrs}$ & 146 & 69.7 & 56.1 & 51.0 & 35.8 & 55.5 & 1485 \\
\hline & $14.00 \mathrm{Hrs}$ & 146 & 70.9 & 57.2 & 50.1 & 35.7 & 56.5 & 1470 \\
\hline & $18.00 \mathrm{Hrs}$ & 146 & 68.1 & 55.4 & 49.6 & 35.8 & 54.6 & 1450 \\
\hline \multirow{3}{*}{ 03-05-2018 } & $11.00 \mathrm{Hrs}$ & 146 & 69.5 & 56.7 & 51.0 & 35.8 & 55.5 & 1356 \\
\hline & $14.00 \mathrm{Hrs}$ & 146 & 70.6 & 57.3 & 50.1 & 35.7 & 56.5 & 1362 \\
\hline & $18.00 \mathrm{Hrs}$ & 146 & 68.7 & 55.6 & 49.6 & 35.8 & 54.6 & 1361 \\
\hline
\end{tabular}

The risks of bacterial or odour contamination are virtually eliminated, as are emissions, dust and fines. The slow and controlled movement of the urea material prevents product abrasion and degradation so that there is no change in particle characteristics or quality. The size distribution of the prills and moisture is the same of BFC IN/OUT hopper no properties of urea changes. The dust generation is continuously removing in the operation of cooling. The dedicated dust recovery system has been installed with BFC. The dust recovery urea solution further recovers in vacuum section, hence no loss in BFC operations. 


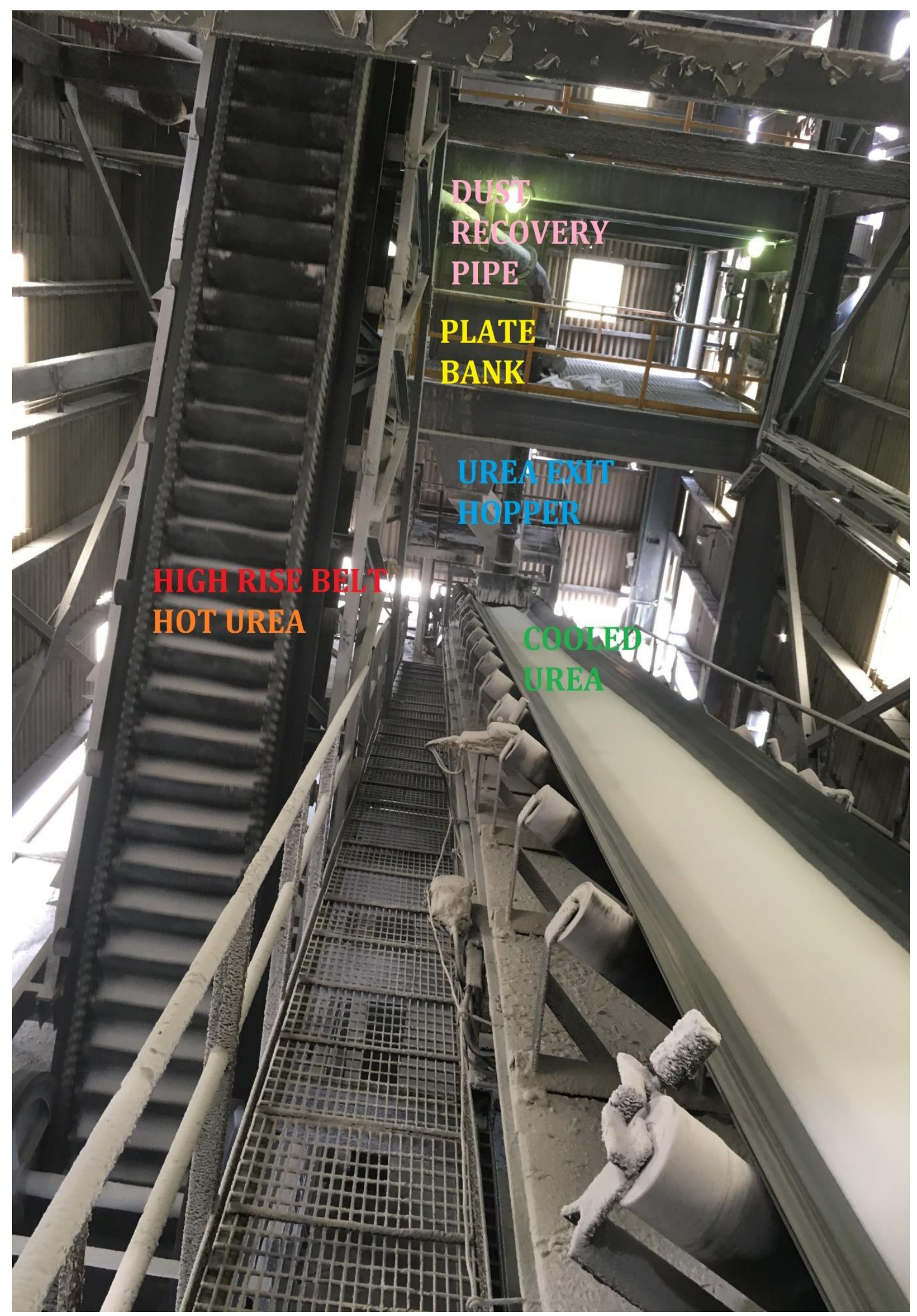

Fig-3 : View of Solex cooler 
3. To reduce Ammonia contents in prills with process conditions The ammonia can be controlled with process parameters. If the free ammonia is present more due to process upset the prills crushing strength is low because hollow prills and generation of dust. The ammonia control table as shown in the table-1, which shows how to reduce ammonia/moisture in urea prills.

4. Urea dust removing from urea prills in conveying system and BFC.

To reduce the caking in urea prills the urea dust must be removed. The dedicated dust recovery system installed in Bulk flow cooler. Bulk flow cooler takes in line in peak summer when prills temperature reach above $60^{\circ} \mathrm{C}$. However it can be also taken in line above $50^{\circ} \mathrm{C}$, according to dew point inside the BFC of air. Since the air used for cooling (see Fig-1) the bulk solids never comes into direct contact with the cooling fluid, the risks of bacterial or odour contamination are virtually eliminated, as are emissions, dust and fines. Because of the varying types and diversity of dust control methods, powder and fine material handlers should consider evaluating causes, problem areas, dust-generating processes and potential management techniques to arrive at the optimum approach for their operation. Categorized as either respirable or inhalable according to particle size, dry, solid dust particles range from about 1 to 100 microns $(\mu \mathrm{m})$ in diameter. According to the U.S. Environmental Protection Agency, inhalable dust particles (larger than $10 \mu \mathrm{m}$ ) are typically caught by the nose, throat or upper respiratory tract. In contrast, respirable dust particles (under $10 \mu \mathrm{m})$ have the potential to penetrate beyond the body's natural cleaning mechanisms, (cilia and mucous membranes) traveling deep into the lungs where they are likely to be retained. Virtually any activity that disturbs bulk material is likely to generate dust; however, crushed, fine and powdered substances pose a unique problem. Bulk conveying operations and trucks or railcars dumping loads of raw material often struggle to manage this fugitive material, as well as any activity involving heavy loading equipment. Because they move large amounts of material at high speeds, conveyors can be a complex source of fugitive material. Transfer points composed of drop chutes, impact points and conveyor enclosures are notorious dust sources unless properly designed, installed and sealed. In fact, with today's larger, faster conveyor systems, virtually the entire belt path can be a contributor to the release of dust.In bunkering system high capacity blowers are installed to suck urea dust. The system containing High capacity blower, Dust absorber D.M. water tank solution transfers pumps, Level indicators and urea density meters.as shown in the figure-3. Urea is quite soluble in water (1gram in $1 \mathrm{~mL}$ ) so there is no question as to the spontaneity of the process at room temperature. This tells us something else about the dissolving of urea in water: the entropy change in the universe is positive. In the case of urea and water the situation looks very promising. Substances are polar, both can hydrogen bond, and while urea is somewhat larger than water it is not grossly out of scale. Urea is difficult to dissolve when too little water is present, and it will be too diluted if too much water is used. The lean solution circulates to improve urea concentration and when urea concentration reached about $25-30 \%$ then solution transfer to Urea line-1 and line-2 plants. As shown in the figure-4. This solution taken in urea dissolving tank and mixed with urea solution tank to recovers in vacuum section.

Size distribution of Urea

\begin{tabular}{|c|c|c|c|c|}
\hline Sr. No. & Sieve size, $\mathrm{mm}$ & Prills, \% & Summary & Size \\
\hline 1 & +2.8 & 1.67 & 1.67 & Over size \\
\hline 2 & $-2.8+2.36$ & 6.43 & \multirow{6}{*}{96.64} & \multirow{6}{*}{ Normal size } \\
\hline 3 & $-2.36+2.0$ & 16.48 & & \\
\hline 4 & $-2.0+1.7$ & 28.1 & & \\
\hline 5 & $-1.7+1.4$ & 28.47 & & \\
\hline 6 & $-1.4+1.18$ & 13.42 & & \\
\hline 7 & $-1.18+1.0$ & 3.74 & & \\
\hline 8 & $-1.0+0.80$ & 0.83 & \multirow[t]{2}{*}{1.69} & \multirow[t]{2}{*}{ Under Size } \\
\hline 9 & -0.80 & 0.86 & & \\
\hline & Total & 100 & 100 & \\
\hline
\end{tabular}

Table-5: Size distribution of urea 